\title{
An Empirical Analysis of the 2000 Corporate Tax Reform in Germany: Effects on Ownership and Control in Listed Companies
}

\author{
Anke Weber
}

November 2005

CWPE 0556

Not to be quoted without permission 
An Empirical Analysis of the 2000 Corporate Tax Reform in Germany: Effects on Ownership and Control in Listed Companies ${ }^{*}$

\author{
Anke Weber ${ }^{\dagger}$ \\ University of Cambridge
}

November 2005

\title{
$\underline{\text { Abstract }}$
}

This paper is a first attempt to analyse the implications of the 2000 corporate tax reform on ownership concentration in Germany. The empirical results document a fall in ownership concentration and a decrease in the power of top institutional owners including the big banks. The description of German corporate governance as a bank-based system may hence no longer apply. However, contrary to what was expected by proponents of the reform, the corporate tax reform did not revolutionise German corporate governance. Ownership concentration in 2005 is still high compared to the Anglo-American economies and an active market for corporate control is not observed.

JEL classification: G30, G32, G38

Keywords: Voting-block statistics, blockholders, corporate control

\footnotetext{
${ }^{*}$ I thank Jeremy Edwards for helpful comments. I am also grateful to Jens Widdra from the Bundesanstalt für Finanzaufsicht for access to data.

${ }^{\dagger}$ Faculty of Economics, Austin Robinson Building, Sidgwick Avenue, Cambridge, CB3 9DD, UK

E-mail: aw299@econ.cam.ac.uk
} 


\section{Introduction}

One of the most significant developments in German corporate governance was the change in corporate income tax law (Körperschaftssteuergesetz), which was introduced in 2000 and took effect at the beginning of 2002. The 2000 corporate tax reform totally abolished the tax on profits from the sale of long-term equity stakes held by banks and large firms. It was expected that the corporate tax reform would encourage firms to sell off their big share blocks on a large scale and hence create a less concentrated ownership structure in Germany (Lane 2004). It was also hoped that the more dispersed ownership would provide investment opportunities for outsiders, make firms more vulnerable to takeovers and thereby create a more active market for shareholder orientation (Deeg 2001).

The change in the corporate income tax law was presumably introduced because many politicians and economists thought that it was useful to create an Anglo-American system with a strong focus on shareholder wealth maximisation in Germany. It was argued that European integration and globalisation, which expand product, labour and capital markets beyond national boundaries expose countries to the pressure of adopting a governance system that comes as close as possible to the outsider controlled model of the Anglo-American economies (Walter 1993). However, the Anglo-American system with its dispersed ownership structure is an exception as typically most economies have very concentrated ownership (La Porta et al 1999). One explanation that has been put forward to explain this high level of ownership concentration is that it may be the result of weak shareholder protection (La Porta et al 1997, 1998). It is hence not clear whether one can expect major changes to ownership concentration in Germany just as a consequence of the corporate tax reform.

By assembling a new and unused dataset, the aim of this paper is to investigate how ownership concentration has changed in Germany as a response to the 2000 corporate tax reform and to thereby assess the extent to which significant changes have taken place in the German system of corporate governance. To the best of our knowledge, it is the first attempt to analyse the effects of the 2000 corporate tax reform on ownership concentration in detail. A dataset describing ownership of German listed companies for the years 1999, 2001, 2003 and 2005 is used. The data is based on the disclosure standard under the 1995 transposition of the European Union's Large Holdings Directive into German law under which companies are required to disclose voting blocks larger than 5\%. The empirical findings document a significant decrease in ownership concentration from 2001 to 2005. It is also found that the power of top institutional owners including the big banks decreases significantly. The description of the German corporate governance system as a bank-based system may hence no longer apply. However, because ownership concentration overall is still very high among listed companies in 2005 and no active takeover market is observed, the findings of this paper suggest that the 2000 corporate tax reform did not revolutionise corporate governance in Germany and that the transformation to a capital market-based system so far has not taken place.

The remainder of this paper is organised as follows: Section 2 provides an overview of the empirical evidence and theories of corporate ownership. Sections 3 and 4 outline the method and data used in this paper. Section 5 presents the results. Section 6 concludes.

\section{Ownership Concentration: Theory and Evidence}

Ownership concentration is a central issue of the theory of corporate governance (Shleifer and Vishny 1997). Until the 1990s it was generally assumed that the widely held corporation was common (Becht and Mayer 2000). However, in the 1990s empirical data revealed that concentrated ownership dominates worldwide with the exception of the US and the UK (La Porta et al 1999). There is very little empirical evidence on whether this concentrated 
ownership that was observed in the 1990s has been stable or whether there have been important changes in ownership structures. Van der Elst (2000) and Wojcik (2003) both observe falling ownership concentration and a growing number of widely held firms in Germany in the late 1990s. Wojcik (2003) concludes that whilst ownership concentration in Germany seems to have fallen in the late 1990s it is still very high in comparison to other countries.

Several explanations have been put forward to explain this very high level of ownership concentration in Germany. It has been argued that the high ownership concentration observed in the traditional system of German corporate governance is necessary for a system with codetermination, because, given the powers of employees; owners could not assure themselves a return on their investment without large shareholdings (Roe 1998). According to La Porta et al (1998), the highly concentrated ownership structure in Germany may also be the result of weak shareholder protection. La Porta et al $(1997,1998)$ argue that the widely held corporation is likely to be more common in countries with good legal protection of minority shareholders because in these countries controlling shareholders are less likely to be expropriated if they lose control through a takeover. Hence, controlling shareholders may be willing to cut their ownership of voting rights in order to raise funds or to diversify. According to this theory, the developments that took place from the mid 1990s until the beginning of the millennium, which strengthened the position of minority shareholders, might have contributed to a more disperse ownership in Germany. Among those developments were the creation of a new supervisory authority, the Bundesaufsichtsamt für den Wertpapierhandel, (BAWe, since 2002 incorporated into the new Bundesanstalt für Finanzaufsicht, BAFin) (Hackethal et al 2005). Furthermore in 2002 the new German takeover law was introduced, which incorporated a mandatory takeover bid (Schmidt 2003). Some authors argue that these developments greatly improved investor protection in Germany and that the assessment of La Porta et al (1998), which views German capital markets as underdeveloped does not seem justified any more (Nowak 2004 and Theissen 2004). However, others stress that the new supervisory authority lacks enforcement power and that it is hence difficult to argue that the new legal elements pave the way for an active market for shareholder orientation (Bhattacharya and Daouk 2004) ${ }^{1}$. It is hence not clear whether one should expect ownership concentration to have fallen as a result of these developments.

Research on the German corporate governance system has not only found a very high level of ownership concentration but has also emphasised that a majority of owners of listed companies are financial and non-financial firms (Franks and Mayer 2001). La Porta et al (1998) claim that Germany is in fact one of the few countries in which financial institutions play an essential role as owners. However, some research also shows that the description of the German system as bank-based is not confirmed by the empirical evidence (Edwards and Nibler 2000). It has been argued that the role of banks in holding equity stakes has been overemphasised. Banks may frequently hold equity stakes as the result of rescuing firms that are in financial distress. Banks may have no desire to hold large equity stakes for control purposes but may simply find that they end up with them as a result of cancelling the debts of financially distressed firms and replacing them with equity stakes. According to this view, it can be expected that the corporate tax reform induced banks to reduce these equity stakes because they no longer faced a large tax bill when selling them.

Non-financial firms also have an essential role as owners and there exist plausible theoretical arguments for why non-financial firms hold equity stakes for control purposes. As Goergen et al (2004) point out for a non-financial firm such as a car manufacturer a large shareholding in a supply firm can yield an important strategic advantage. By being represented on the supervisory board of the supplier, the car manufacturer can obtain private information on the

\footnotetext{
${ }^{1}$ For an exhaustive list of developments see Höpner (2001)
} 
firm's cost structure or on supply contracts with competitors. The presence on the supervisory board can also mitigate hold-up problems. Since the supplier can put the car manufacturer into a difficult position by not delivering the necessary car supplies on time, the manufacturer has a strong incentive to buy equity in the supply firm and hence to ensure the delivery. If the above arguments are correct, then it is likely that the 2000 corporate tax reform would have a less significant effect on ownership of non-financial firms as many of these firms enjoy benefits of control from holding large voting blocks.

It is hence not only important to assess whether ownership concentration has been stable, it is also essential to investigate whether the structure of owners of listed companies has changed and whether top institutional owners such as big banks maintained their power in corporate governance. There are several studies on the structure of share ownership in Germany before the corporate tax reform was implemented. Prigge (1998) covering the period from 1984-1996 finds that the share of non-financial corporations is growing whilst that of financial corporations is stable. Wojcik (2003) investigating data for the years 1997 and 2001 finds that the share of non-financial corporations is increasing whilst that of the financial corporations is falling. There is very little research on whether the role of top institutional owners has been changing. However, the observations of O'Sullivan (2000) suggest that big banks and insurers are selling their stakes and leaving boardrooms.

Related to the question of whether top-institutional owners have maintained their power in German corporate governance is whether the role of cross-holdings has changed. Crossholdings have been shown to be very significant in the past, especially among those companies that have been referred to as the top 7 institutional owners (Prowse 1994, Wenger and Kaserer 1998). Among those seven companies are the Deutsche Bank AG, the Allianz AG, the E.ON AG, the Dresdner Bank AG, the Bayerische Hypo- und Vereinsbank AG, the RWE AG and the Münchener Rückversicherungs-Gesellschaft AG. The Allianz AG has often been called the spider of the web of cross-holdings because it holds voting rights in almost all of the other top-institutional owners (Story and Walter 1997). There is very little empirical evidence on whether the role of cross-holdings was already changing before the implementation of the corporate tax reform in 2002. Wojcik (2003) finds that the crossholdings among the top 7 owners remain largely unchanged between 1997 and 2001. Whilst politicians and economists expected that the corporate tax reform would reduce the scope of cross-holdings between the top-institutional holders, further empirical evidence is needed.

\section{Data and Method}

\section{A. Data}

The data used in this paper is provided by the Bundesanstalt für Finanzaufsicht, BAFin (formerly the Bundesaufsichtsamt für den Wertpapierhandel, BAWe) for four points in time: 1st January 1999, 1st January 2001, 1st January 2003 and 1st January 2005. The dataset is based on the disclosure standard that implements the European Union's Large Holdings Directive (88/627/EEC) and the German Securities Trading Act (Wertpapierhandelsgesetz, $\mathrm{WpHG}$ ). Under this law all voting rights at the command of blockholders controlling at least $5 \%$ of the voting rights have to be disclosed. This obligation refers to both direct and indirect holdings of voting rights. ${ }^{2}$ An entity controls an indirect voting right from a share that he does not own. This may be the case if an entity controls a direct shareholder or has been entrusted with the responsibility for his shares (Wojcik 2003). The law also requires the disclosure of identity of those in command of voting power irrespective of their 'distance' from the listed

\footnotetext{
${ }^{2}$ The term holding, blockholding and voting block will be used interchangeably to denote the percentage of voting rights in a company held by an entity both directly and indirectly.
} 
company (Becht and Böhmer 2003). The database hence consists of the following parts: all domestic companies listed on amtlicher Handel (Official market) and the holders of major voting rights in these companies. A detailed investigation of how voting power is measured under the WpHG as well as of the shortcomings of the database can be found in Becht and Böhmer (2003). In addition to the dataset on major holding rights in listed companies, the FTSE Global Classification System (Version 2002) is used in order to classify the listed companies into different industries.

\section{B. Method}

According to the theoretical and empirical evidence presented in Section 3, it is expected that ownership concentration decreases between 1999 and 2005. If ownership falls continuously from 1999 to 2005, then the drop in ownership could be attributed to those developments in Germany that strengthened the power of minority shareholders. Hence, if the corporate tax reform had any effect at all on ownership concentration, acceleration in the decline in ownership concentration should be observed between 2001 and 2003. The first hypothesis to be tested is hence the following:

\section{Hypothesis 1: The concentration of blockholdings falls between 1999 and 2005 and the fall in concentration is greater between 2001 and 2003 than between 1999 and 2001.}

In order to examine how ownership concentration changes between 1999 and 2005, the whole population of listed firms in 1999, 2001, 2003 and 2005 is analysed and the empirical distribution and summary statistics for ultimate voting blocks are computed. Voting Blocks for each firm are ranked according to their size and we compute the median size of the first, second and third largest voting block. We also compute the mean and median size of the sum of the first, second and third largest voting block in each firm as well as the mean and median size of the sum of all voting blocks in each firm.

The listed firms in the sample are then classified according to the FTSE Global Classification System and summary statistics for each industry are computed in order to determine how concentration has changed across different industries. From the evidence on ownership concentration in Germany it is not clear what to expect. However, it is very probable that holders of voting rights in the non-financial industries range from financial to non-financial corporations and also include individuals. Since a general fall in ownership concentration is expected and holders of voting rights in non-financial industries probably include a mix of all blockholders, a fall in the average concentration across these industries seems likely. In the financial industries the majority of holders are likely to be financial corporations themselves. Since financial corporations often may not hold voting rights for control purposes, it can be expected that these blocks are sold as a result of the corporate tax reform. A more or less universal decrease in ownership concentration across non-financial and financial industries is hence expected. The following hypothesis is tested:

\section{Hypothesis 2: The decrease in ownership concentration across different industries is nearly universal.}

It is also investigated whether there has been a change in the power of blockholders and especially whether banks and other financial firms, which have often been characterised as an important part of the German corporate governance system, have lost some of their power in terms of blockholdings. It is hence examined how voting power has changed across blockholders. According to the theoretical and empirical evidence provided in Section 3, financial and non-financial corporations are the most important blockholders. It is likely that 
as a result of the corporate tax reform financial firms sold large blocks of their holdings because very often they are not held for control purposes. A smaller reduction in the blockholdings of non-financial firms can be expected, since non-financial firms hold voting rights for control and strategic purposes. The following hypothesis is hence tested:

Hypothesis 3: The two most important holders of major voting rights are financial and nonfinancial firms. Whilst the share of non-financial firms in listed companies falls at best slightly as a result of the corporate tax reform, financial firms experience a significant decline between 2001 and 2005.

The above hypothesis is investigated by calculating the number of voting blocks for each type of blockholder as well as by providing summary statistics such as the mean and median size of voting blocks for each type of blockholder. Following Becht and Böhmer (2003) we divide blockholders into the following categories: industrial firms, individuals, banks, holdings (Verwaltungsgesellschaften), insurance firms, investment firms (Beteiligungsgesellschaften), public, associations, worker/family pool, coops, foundations and foreign companies. First, all listed companies are investigated. Since cross-holdings among financial companies are very common (Franks and Mayer 2001), we then investigate blockholdings across all non-financial companies.

The fourth hypothesis to be tested relates to the power of the top institutional owners such as the big banks. According to the empirical and theoretical evidence presented in section 3, one would expect that the top-institutional owners lost some of their power between 2001 and 2005. There is very limited evidence available on the scope of cross-holdings. However, since many economists expected that the corporate tax reform would lead to an erosion of the web of cross-holdings, the following is hypothesised:

Hypothesis 4: The power of the top-institutional owners decreases between 2001 and 2005 and there is an erosion of the web of cross-holdings between the top 7 institutional owners.

In order to assess whether the role of top institutional owners has changed, the number of blocks controlled by top institutional owners are identified. We list all blockholders controlling votes in five or more listed companies in either 2001 or 2005 and investigate whether they experience a decline in the number of voting blocks controlled and in the average size of voting blocks. It is then investigated whether the role of cross-holdings has changed between 2001 and 2005. We examine how many of the holders of major voting rights in the top 7 institutional owners are top-institutional owners themselves and whether there have been significant changes in the size of their voting blocks between 2001 and 2005 .

\section{Results}

A. Hypothesis 1: The level of ownership concentration

Between 1999 and 2005 there is a substantial rise in the number of listed companies under consideration, with the number of listed companies rising from 425 in 1999 to 753 in 2005. Figure 1 shows the median size of the first, second and third largest voting block in 1999, 2001, 2003 and 2005. The median size of all voting blocks is also shown. It can be seen that there is a significant drop in the median size of the first, second and third largest voting block from 2001 to 2003 and from 2003 to 2005 . The median size of the largest voting block seems to be affected most.

Table 1 shows that the mean size of the largest voting block $\left(\mathrm{C}_{1}\right)$ falls from $59.76 \%$ in 1999 to $52.62 \%$ in 2005 . This decrease is not continuous as there is a slight increase from 1999 to 2001. From 2001 and 2003, there is a significant fall in the mean size of the largest voting 
block with the mean size falling by almost $6 \%$. From 2003 to 2005 there is again a decrease of approximately $2 \%$ in the mean size of the largest voting block, which is however, smaller than from 2001 to 2003. The median size of the largest voting block also falls between 1999 and 2005. Again there is a slight increase from 1999 to 2001. From 2001 to 2005 the median size of the largest voting block falls by more than $12 \%$, from $62.81 \%$ to $50.1 \%$. The most significant decrease takes place between the years 2001 and 2003, between which the median size falls by almost 10 percent.

Voting power is highly concentrated in most companies. When there exist multiple voting blocks in the same firm they do not add much voting power. Adding the second and third largest voting block $\left(\mathrm{C}_{3}\right)$ increases the mean concentration ration by $11.5 \%$ to $71.26 \%$ in $1999^{3}$. Including all blockholders $\left(\mathrm{C}_{\text {all }}\right)$ increases the mean concentration ratio to $73.29 \%$ in 1999.

As can be seen from table 1 , the mean and median concentration ratio of $\mathrm{C}_{3}$ and $\mathrm{C}_{\text {all }}$ follow more or less the same pattern as the mean and median of $\mathrm{C}_{1}$. Whilst there is a slight increase in voting power from 1999 to 2001, there is a significant decrease in the mean and median of $\mathrm{C}_{3}$ and $\mathrm{C}_{\text {all }}$ from 2001 to 2005 . These results suggest that voting power in companies falls between 2001 and 2005 and that the most significant drop takes place between 2001 and 2003.

Table 1 also shows the empirical distribution of blockholdings. The block size distribution confirms that the concentration of voting rights has fallen between 1999 and 2005 and that ownership concentration has been and still is very concentrated. At the lower end of the distribution, $15.5 \%$ of each company's largest voting block is smaller than $25 \%$ in 1999 whereas in $2005,25.2 \%$ are smaller than $25 \%$. At the top end of the distribution, $39.1 \%$ of voting blocks are greater than $75 \%$ in 1999 and $31.6 \%$ of voting blocks are greater than $75 \%$ in 2005.

To summarise, the findings presented in this section clearly support hypothesis 1 . There is a significant fall in ownership concentration as measured by the concentration of voting blocks among listed companies between 1999 and 2005. The most significant decrease takes place between 2001 and 2003, which suggests that the corporate tax reform had a significant effect on ownership concentration. Nevertheless ownership of listed companies is still very concentrated in 2005 as indicated by the mean and median size of the largest voting block, which still exceeds 50\% and the block size distribution.

\section{B. Hypothesis 2: Changes in ownership concentration across different industries}

Table 2 shows the sector structure of listed companies in 2001 and 2005. It can be seen that whilst some industries experience a rising share of listed companies between 2001 and 2005, the share of other industries as a proportion of total listed companies declines. The industry that experiences the highest growth in the number of listed companies is the information technology and hardware sector. In $2001,1.8 \%$ of listed companies are in the IT sector, whereas in 2005 almost $11 \%$ of listed companies are in the IT sector. The telecommunication services sector also experiences a rise in listed companies with the percentage of listed companies almost tripling between 2001 and 2005. Other industries show a marked decline in listed companies. As table 2 shows, the number of banks, insurance companies and investment firms as a proportion of total listed companies decreases between 2001 and 2005 . In addition there is a significant fall in the number of firms as a percentage of all listed

\footnotetext{
${ }^{3} \mathrm{C}_{\mathrm{n}}$ is the sum of the $\mathrm{n}$ largest blockholdings in each listed companies. For example if there were 3 listed companies in the sample, then the mean of $\mathrm{C}_{\mathrm{n}}$ is computed by adding up the sums of the $n$ largest blockholdings in each company and dividing this sum by 3 .
} 
companies in the building and construction, steel and automobile industries. This suggests, that the importance of the technology sectors has increased whilst that of the more traditional industries decreased between 2001 and 2005. Changes in ownership concentration across different industries are also examined. Figures 2 and 3 show the median size of voting blocks in the most important non-financial as well as financial industries in 2001 and 2005. In Figure 2 it can be seen that the decrease in ownership concentration across the non-financial sector is almost universal across industries. The majority of industries experience a marked decline in the median size of voting blocks between 2001 and 2005. Among those industries that experience a significant decline are telecommunication services, transport, pharmaceuticals and biotechnology, electronics, chemicals and steel. Whilst Figure 2 also shows an increase in the median size of voting blocks in industries such as energy, beverages and personal care and household products, the number of observations for these industries is in general quite small and thus the results are not very conclusive. Figure 3 shows the median size of voting blocks in the financial sector industries. It can be seen that the insurance industry experiences a large fall in the median size of voting blocks between 2001 and 2005. Investment companies and the specialty and finance industry also experience a decline which is however not as marked as in the insurance industry. Banks and real estate experience a rise in the size of the median voting block. With the exception of banks and real estate, there hence seems to be a decrease in ownership concentration amongst the industries in the financial sector. Whilst this decrease is not universal, overall it seems as if there had been a significant decrease of ownership concentration across the financial industries. These results hence support hypothesis 2 .

\section{Hypothesis 3: Control across blockholders}

There are 921 blockholdings in 2001 compared to 1679 blockholdings in 2005. Table 3 shows the distribution of blockholdings in all listed companies for 2001 and 2005. It can be seen that individuals and families hold most blocks in 2001 and 2005, but that the mean holding (24.9\% in 2001 and $25.1 \%$ in 2005) is smaller than that of industrial firms $(53.3 \%$ in 2001 and $41 \%$ in 2005). Table 3 also shows that the share of the entities in the financial sector is small compared to the share of individuals and industrial companies. The percentage of total blockholdings of the whole financial sector is $29.9 \%$ in 2001 and $24.8 \%$ in 2005 , which is less than that of individuals in both years. This observation gives support to the observation of Edwards and Nibler (2000) and Edwards and Fisher (1994) that the role of financial companies and especially banks is limited. These findings also partially contradict hypothesis 3 , since the largest groups of blockholders are wealthy families and non-financial corporations followed by financial institutions. These observations do, however, confirm the findings of Böhmer and Becht (2001) who come to the same conclusion.

Table 4 shows the distribution of blockholdings in non-financial companies. It can be seen that the share of individuals and families is rising in terms of the proportion of blockholdings held but that the mean size of their blockholdings is falling. The share of industrial firms is falling sharply from 2001 to 2005 in terms of the number of blocks held and the mean size of their blockholdings. Foreign firms experience a rising share of voting blocks but a decrease in the mean size of their blockholdings. The position of the financial sector seems to be deteriorating significantly although the big three banks (Deutsche Bank, Dresdner Bank and Commerzbank) are an exception to this to some extent ${ }^{4}$. The big three banks as well insurance companies experience a significant decline in terms of the percentage of blocks held between 2001 and 2005. Insurance companies also experience a decline in the mean size of their blockholdings, whereas the mean size of blockholdings of the three big banks increases

\footnotetext{
${ }^{4}$ In 2001 Dresdner bank still exists as a separate entity whereas in 2005 in belongs to the Allianz Group. Hence in 2005 , there are only 2 out of the big 3 banks left
} 
between 2001 and 2005. As table 4 shows, this increase is however, offset by the sharp decline in the mean size of blockholdings of the other banks ${ }^{5}$.

There is hence evidence that the big firms such as non-financial corporations and companies in the financial sector are selling large blocks of their voting rights. The results partly contradict hypothesis 3 since we observe a significant decrease in the power of both nonfinancial as well as financial firms in terms of the number and size of their blockholdings. The reason for this may be that the blocks of shares held by non-financial corporations are very often blocks of shares in 'unrelated' firms and hence the control benefits are limited ${ }^{6}$.

The results in this section hence support the observation of O'Sullivan (2000) that insurance companies and banks are losing some of their power. They also confirm the findings of the earlier sections namely that the 2000 corporate tax reform had a significant effect on ownership concentration and that it has led to a decrease in the power of blockholders. The next section examines changes in the power of the top-institutional holders in more detail by focusing on the identity of large shareholders.

\section{Hypothesis 4: The role of top-institutional owners}

First, the number of blockholders and the number of their holdings in listed companies in 2001 and 2005 are analysed. The results are shown in table 5. It can be seen that most shareholders $(87.17 \%$ in 2001 and $88.8 \%$ in 2005$)$ hold just one voting block. It is then investigated who the holders of the multiple voting blocks are. Table 6 lists all blockholders controlling votes in five or more listed companies in either 2001 or 2005 . It can be seen that in 2001 and 2005 the holders of multiple voting blocks are mostly banks and insurance companies. Table 6 also shows that most of those companies that have often been quoted as the top 7 institutional holders are experiencing a decline in the number of voting blocks they control. Between 2001 and 2005, Deutsche Bank AG halves its holdings in listed companies from 20 to 10. The Allianz AG increases its holdings from 19 to 21 between 2001 and 2005. However, since in 2005 the Dresdner Bank, which holds 13 voting blocks in 2001, belongs to the Allianz AG, there is evidence that the Allianz AG sells some of its holdings between 2001 and 2005. The E.ON AG and RWE AG decrease their holdings from 12 voting blocks to 8 and 11 voting blocks to 7 respectively between 2001 and 2005. Whilst the Bayerische Hypound Vereinsbank AG holds 11 voting blocks in 2001 as well as in 2005, the mean and median of its voting blocks decreases significantly between 2001 and 2005, with the mean falling from $52.6 \%$ to $37.8 \%$. The Münchener Rückversicherungsgesellschaft is the only institutional holder of the top 7 that increases its holdings from 2001 to 2005 . However, the mean of its holding blocks is falling from approximately $31 \%$ to $27 \%$. Table 6 also shows that in 2005 there are some foreign companies with multiple holdings, the mean of which is in general relatively small. These findings and those of the previous section suggests that there is an increase in the number of foreign holders of voting rights in Germany, but that the average voting block held by these companies is relatively small.

It is also investigated whether the scope of cross-holdings among the top 7 institutional owners changes between 2001 and 2005. The results are shown in table 7. It can be seen that a majority of the top 7 institutional owners that hold voting blocks in one of the other top 7 institutional companies sell some of these stakes between 2001 and 2005 and that the size of cross-holdings decreases significantly between 2001 and 2005. Since there is evidence

\footnotetext{
${ }^{5}$ The most important group in the category 'other banks' are the Landesbanken, which are usually owned by the governments of the 'Länder'

${ }^{6}$ This is in fact exactly what Schmidt (2004) observes. In contrast to Rieckers and Spindler (2004) who claim that the blocks of shares held by other corporations are part of complex structures of groups of related companies, Schmidt claims that the majority of holdings of non-financial companies are in fact in completely unrelated companies.
} 
provided by Wojcik that the role of cross-holdings did not change between 1997 and 2001, this suggests a significant influence of the 2000 corporate tax reform on the structure of ownership in Germany.

The results in this section hence strongly suggest that the top-institutional holders have lost some of their power as holders of voting blocks, with the Deutsche Bank AG being a particularly striking example because it halved its voting rights between 2001 and 2005 . There also has been an erosion of the web of cross-holdings between the top 7 institutional owners. Hypothesis 4 is hence confirmed by the empirical findings of this paper. The conclusions of the earlier sections are also strengthened, namely that the corporate tax reform had a significant effect not only on ownership concentration overall but also on the power of top institutional owners in terms of their blockholdings. There is furthermore evidence that the corporate tax reform led to a disintegration of the web of cross-holdings between the top 7 institutional owners just as had been expected by the proponents of the reform.

\section{$\underline{\text { V. Conclusion }}$}

According to the evidence provided in this paper the corporate tax reform had a significant effect on ownership concentration in Germany. The mean and median size of major voting blocks fell significantly between 1999 and 2005, with the most significant decline taking place between 2001 and 2003. This suggests, that it is possible to isolate the effects of the corporate tax reform from other major developments in German corporate governance, which strengthened the power of minority shareholders to some extent but which took place before 2000. It was also expected that the corporate tax reform would induce the top institutional owners such as the big banks and insurance companies to sell their blockholdings. The empirical evidence clearly confirms this. The findings of this paper document that as a result of the 2000 corporate tax reform the power of the big blockholders, such as banks and insurance companies diminished and that the web of cross-holdings among the topinstitutional owners has been disintegrated. This also suggests a significant influence of the 2000 corporate tax reform on the structure of ownership in Germany.

Furthermore there is evidence that the role of banks changed between 2001 and 2005 as the big banks such as the Deutsche Bank sold many of their equity stakes and hence lost some of their power as major holders of voting rights in listed companies. According to Hackethal et al (2005), the big banks have also reduced their corporate lending activities considerably and seem to be trying to become what might almost be described as investment banks. These two developments together suggest, that the big banks are reducing their active involvement in German corporate governance. Since the importance of banks has often been presented as a building block of the German corporate governance system, these changes are quite fundamental and it may hence no longer be accurate to refer to the German corporate governance system as a bank-based system.

However, even though the corporate tax reform had a significant effect on ownership concentration and on the power of the top-institutional blockholders, the change in the corporate income tax law did not revolutionise German corporate governance. Ownership concentration is still very high in Germany compared to the dispersed ownership structure that is found in the Anglo-American countries. It also very much seems as if the corporate tax reform had a once and for all effect on ownership concentration, since deconcentration, although still very significant, slowed down between 2003 and 2005 compared to 2001 and 2003. An explanation for this may be that the system of codetermination, which requires concentrated ownership, is still in place and that it is debatable whether the power of minority shareholders has been sufficiently strengthened.

There is also yet no evidence that the change in the capital gains taxation resulted in a wave of takeovers (Hackethal et al 2005). Whilst the Mannesmann-Vodaphone take-over battle of 
1999 and 2000 was a hostile one, the success of Vodaphone in taking over Mannesmann has not been the beginning of an active public takeover market in Germany. The reasons that have always made hostile tender offers difficult in Germany, such as the legal structure of German joint stock corporations with the codetermination as part of it still apply (Schmidt 2004). In addition, according to Becht (1999) dispersed ownership is a prerequisite for an open market for corporate control and the concentrated ownership that still prevails in Germany protects companies from hostile bids. Hence, although many significant changes have been observed in the German corporate governance system, the transformation to a capital market-based system so far has not taken place. 
$\underline{\text { References }}$

BAFin (Bundesanstalt für Finanzaufsicht), 1999, 2001, 2003, 2005. Bedeutende Stimmrechtsanteile an amtlich notierten Aktiengesellschaften (major holdings of voting rights in German listed companies). Frankfurt a.M.

Bhattacharya, U., Daouk, H., 2004. When No Law is Better than a Good Law. Working Paper, Indiana University.

Becht, M., 1999. European Corporate Governance: Trading off Liquidity against Control in Germany. www.ecgn.ulb.ac.be.

Becht, M., Boehmer, E., 2003. Voting Control in German Corporations. International Review of Law and Economics, 23, pp.1-29.

Becht, M., Mayer, C., 2000. The Control of Corporate Europe. www.ecgn.ulb.ac.be.

Böhmer, E., Becht, M., 2001. Ownership and Voting Power in Germany, in: Barca, F., Becht, M. (Eds.), The Control of Corporate Europe, Oxford University Press, London, pp.128-153.

Deeg, R., 2001. Institutional Change and the Uses and Limits of Path Dependancy: The Case of German Finance. MPIfG Discussion Paper 01/6, Max Planck Institut für Gesellschaftsforschung, Köln.

Edwards, J., Fischer, K., 1994. Banks, Finance and Investment in Germany. Cambridge University Press, Cambridge.

Edwards, J., Nibler, M., 2000. Corporate Governance in Germany: The Role of Banks and Ownership Concentration. Economic Policy, 31, pp.237-260.

Franks, J., Mayer, C., 2001. Ownership and Control of German Corporations. Review of Financial Studies, 14, pp. 943-977.

FTSE Global Classification System, Version January 2002.

Goergen, M., Manjon, M.C., Renneboog, L., 2004. Recent Developments in German Corporate Governance. ECGI Working Paper Series in Finance, Working Paper No. 41.

Hackethal, A., Schmidt, R.H., Tyrell, M., 2005. Banks and German Corporate Governance: On the Way to a Capital Market-Based System? Corporate Governance: An International Review, 13 (3), pp. 397-407.

Höpner, M., 2001. Corporate Governance in Transition: Ten Empirical Findings on Shareholder Value and Industrial Relations in Germany. Discussion Paper 01/5, Köln: Max Planck Institut für Gesellschaftsforschung.

Lane, C., 2004. Institutional Transformation and System Change: Changes in Corporate Governance of German Corporations. Sociological Series, Institute for Advanced Studies, Vienna.

La Porta, R., Lopez-de-Silanes, F., Shleifer, A., Vishny, R.W., 1997. Legal Determinants of External Finance. Journal of Finance, 52, 1131-1150.

La Porta, R., Lopez-de-Silanes, F., Shleifer, A., Vishny, R.W., 1998. Law and Finance. Journal of Political Economy, 106, pp.1113-1155.

La Porta, R., Lopez-de-Silanes, F., Shleifer, A., Vishny, R.W., 1999. Corporate Ownership Around The World. Journal of Finance, 54, pp.471-517.

Nowak, E., 2004. Investor Protection and Capital Market Regulation in Germany, in: Krahnen, J.P., Schmidt, R.H., (Eds.), The German Financial System, Oxford University Press, Oxford, pp. 425-450.

O'Sullivan, M., 2000. Contests for Corporate Control: Corporate Governance and Economic Performance in the United States and Germany. Oxford University Press, Oxford.

Prigge, S., 1998. A Survey of German Corporate Governance, in Hopt, K.J., Kanda, H., Roe M.J., Wymeersch E., Prigge, S., (Eds.), Comparative Corporate Governance: The State of the Art and Emerging Research, Clarendon Press, Oxford, pp. 943-1045. 
Prowse, S.D., 1994. Corporate Governance in an International Perspective. BIS Economic Papers, 41, Bank for International Settlements, Basel.

Rieckers, O., Spindler, G., 2004. Corporate Governance: Legal Aspects, in Krahnen, J.P., Schmidt, R.H., (Eds.), The German Financial System, Oxford University Press, Oxford, pp. 350-386.

Roe, M.J., 1998. German Co-determination and German Securities Markets, in Hopt, K.J., Kanda, H., Roe M.J., Wymeersch E., Prigge, S., (Eds.), Comparative Corporate Governance: The State of the Art and Emerging Research, Clarendon Press, Oxford, pp.361-373.

Schmidt, R.H., 2004. Corporate Governance in Germany: An Economic Perspective, in Krahnen, J.P., Schmidt, R.H., (Eds.), The German Financial System, Oxford University Press, Oxford, pp.386-425.

Shleifer, A., Vishny, R.W., 1997. A Survey of Corporate Governance. Journal of Finance, 52, pp.737-783.

Theissen, E., 2004. Organised Equity Markets, in Krahnen, J.P., Schmidt, R.H., (Eds.), The German Financial System, Oxford University Press, Oxford, pp. 139-163.

Story, J., Walter, I., 1997. Political Economy of Financial Integration in Europe: The Battle of the Systems, Manchester University Press, Manchester.

Van der Elst, C., 2000. The Equity Markets, Ownership Structures and Control: Towards an International Harmonisation?. Financial Law Institute Working Paper, Gent University.

Walter, I., 1993. The Battle of the Systems, Institut für Weltwirtschaft, Kiel.

Wenger, E., Kaserer, C., 1998. German Banks and Corporate Governance: A Critical View, in Hopt, K.J., Kanda, H., Roe M.J., Wymeersch E., Prigge, S., (Eds.), Comparative Corporate Governance: The State of the Art and Emerging Research, Clarendon Press, Oxford, pp. 499-537.

Wojcik, D., 2003. Change in the German Model of Corporate Governance: Evidence from Blockholdings 1997-2001. Environment and Planning, 35, pp. 1431-1458. 
Appendix A

Figure 1, Figure 2, Figure 3, Table 1, Table 2, Table 3, Table 4, Table 5, Table 6, Table 7

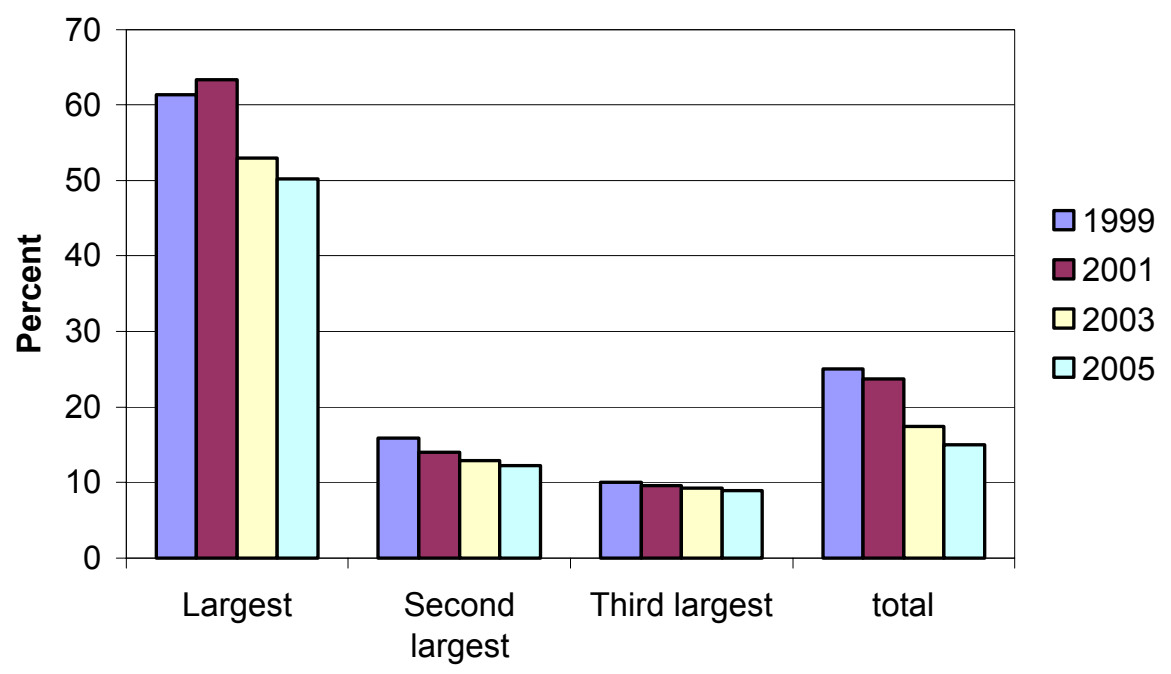

Figure 1: Median size of voting block held by first, second, third largest holder and of all voting blocks 
Table 1: Empirical Distribution of Voting Blocks

\begin{tabular}{|c|c|c|c|c|c|c|c|}
\hline \multirow[t]{2}{*}{ Year } & Range & \multicolumn{2}{|c|}{ C1 } & \multicolumn{2}{|c|}{ C3 } & \multicolumn{2}{|c|}{ C all } \\
\hline & & Frequency & Jercentag & requenc & Jercentag & requenc & ercentage \\
\hline \multicolumn{8}{|c|}{ A.Empirical distribution } \\
\hline \multirow[t]{5}{*}{1999} & $0-24.99 \%$ & 66 & 15.53 & 27 & 6.35 & 27 & 6.35 \\
\hline & $25-49.99 \%$ & 81 & 19.06 & 59 & 13.88 & 45 & 10.59 \\
\hline & $50-74.99 \%$ & 112 & 26.35 & 106 & 24.94 & 104 & 24.47 \\
\hline & $75-100 \%$ & 166 & 39.06 & 233 & 54.82 & 249 & 58.59 \\
\hline & Total & 425 & 100.00 & 425 & 100.00 & 425 & 100.00 \\
\hline \multirow[t]{5}{*}{2001} & $0-24.99 \%$ & 74 & 16.30 & 26 & 5.73 & 25 & 5.51 \\
\hline & $25-49.99 \%$ & 87 & 19.16 & 73 & 16.08 & 56 & 12.33 \\
\hline & $50-74.99 \%$ & 109 & 24.01 & 105 & 23.13 & 106 & 23.35 \\
\hline & $75-100 \%$ & 184 & 40.53 & 250 & 55.07 & 267 & 58.81 \\
\hline & Total & 454 & 100.00 & 454 & 100.00 & 454 & 100.00 \\
\hline \multirow[t]{5}{*}{2003} & $0-24.99 \%$ & 159 & 23.31 & 79 & 11.58 & 73 & 10.70 \\
\hline & $25-49.99 \%$ & 142 & 20.82 & 114 & 16.72 & 94 & 13.78 \\
\hline & $50-74.99 \%$ & 148 & 21.70 & 182 & 26.69 & 185 & 27.13 \\
\hline & $75-100 \%$ & 233 & 34.16 & 307 & 45.01 & 330 & 48.39 \\
\hline & Total & 682 & 100.00 & 682 & 100.00 & 682 & 100.00 \\
\hline \multirow[t]{7}{*}{2005} & $0-24.99 \%$ & 190 & 25.23 & 85 & 11.29 & 80 & 10.62 \\
\hline & $25-49.99 \%$ & 175 & 23.24 & 149 & 19.79 & 124 & 16.47 \\
\hline & $50-74.99 \%$ & 150 & 19.92 & 198 & 26.29 & 204 & 27.09 \\
\hline & $75-100 \%$ & 238 & 31.61 & 321 & 42.63 & 345 & 45.82 \\
\hline & Total & 753 & 100.00 & 753 & 100.00 & 753 & 100.00 \\
\hline & \multicolumn{7}{|l|}{$\begin{array}{l}\text { B. Descriptive } \\
\text { Statistics }\end{array}$} \\
\hline & & Mean & Median & Mean & Median & Mean & Median \\
\hline 1999 & & 59.76 & 61.40 & 71.26 & 76.10 & 73.29 & 79.00 \\
\hline 2001 & & 60.16 & 62.81 & 71.22 & 77.48 & 73.59 & 80.99 \\
\hline 2003 & & 54.84 & 52.90 & 65.44 & 69.59 & 67.45 & 73.80 \\
\hline 2005 & & 52.62 & 50.10 & 64.15 & 66.50 & 66.80 & 70.63 \\
\hline
\end{tabular}


Table 2: Industry structure of listed companies

\begin{tabular}{|c|c|c|c|c|}
\hline Industry & $\begin{array}{l}\text { No. of } \\
\text { firms }\end{array}$ & $\%$ of total firms & $\begin{array}{l}\text { No. of } \\
\text { firms }\end{array}$ & $\%$ of total firms \\
\hline & 2001 & & 2005 & \\
\hline Aerospace and Defense & 0 & 0.00 & 1 & 0.13 \\
\hline Automobiles and Parts & 18 & 3.96 & 18 & 2.39 \\
\hline Banks & 27 & 5.95 & 28 & 3.72 \\
\hline Beverages & 27 & 5.95 & 23 & 3.05 \\
\hline Chemicals & 26 & 5.73 & 26 & 3.45 \\
\hline Construction and Building materials & 42 & 9.25 & 45 & 5.98 \\
\hline Diversified Industrials & 5 & 1.10 & 12 & 1.59 \\
\hline Electronic and Electrical Equipment & 14 & 3.08 & 33 & 4.38 \\
\hline Energy & 14 & 3.08 & 17 & 2.26 \\
\hline Engineering and Machinery & 32 & 7.05 & 38 & 5.05 \\
\hline Food Producers and Processors & 7 & 1.54 & 11 & 1.46 \\
\hline Forestry and Paper & 5 & 1.10 & 4 & 0.53 \\
\hline General Retailing & 16 & 3.52 & 22 & 2.92 \\
\hline Health & 7 & 1.54 & 21 & 2.79 \\
\hline Household Goods and Textiles & 40 & 8.81 & 52 & 6.91 \\
\hline $\begin{array}{l}\text { Information Technology and } \\
\text { Hardware }\end{array}$ & 8 & 1.76 & 81 & 10.76 \\
\hline Insurance & 18 & 3.96 & 16 & 2.12 \\
\hline Investment Companies & 16 & 3.52 & 32 & 4.25 \\
\hline Leisure, Entertainment and Hotels & 12 & 2.64 & 34 & 4.52 \\
\hline Media and Photography & 2 & 0.44 & 28 & 3.72 \\
\hline Mining & 1 & 0.22 & 2 & 0.27 \\
\hline Oil and Gas & 0 & 0.00 & 2 & 0.27 \\
\hline $\begin{array}{l}\text { Personal Care and Household } \\
\text { Products }\end{array}$ & 3 & 0.66 & 4 & 0.53 \\
\hline Pharmaceuticals and Biotechnology & 12 & 2.64 & 24 & 3.19 \\
\hline Real Estate & 22 & 4.85 & 29 & 3.85 \\
\hline Specialty and other Finance & 21 & 4.63 & 35 & 4.65 \\
\hline Steel and other Metals & 14 & 3.08 & 10 & 1.33 \\
\hline Support Services & 6 & 1.32 & 30 & 3.98 \\
\hline Telecommunication Services & 4 & 0.88 & 21 & 2.79 \\
\hline Transport & 9 & 1.98 & 17 & 2.26 \\
\hline Unspecified & 13 & 2.86 & 31 & 4.12 \\
\hline Utilities & 13 & 2.86 & 6 & 0.80 \\
\hline Total & 454 & 100.00 & 753 & 100.00 \\
\hline
\end{tabular}




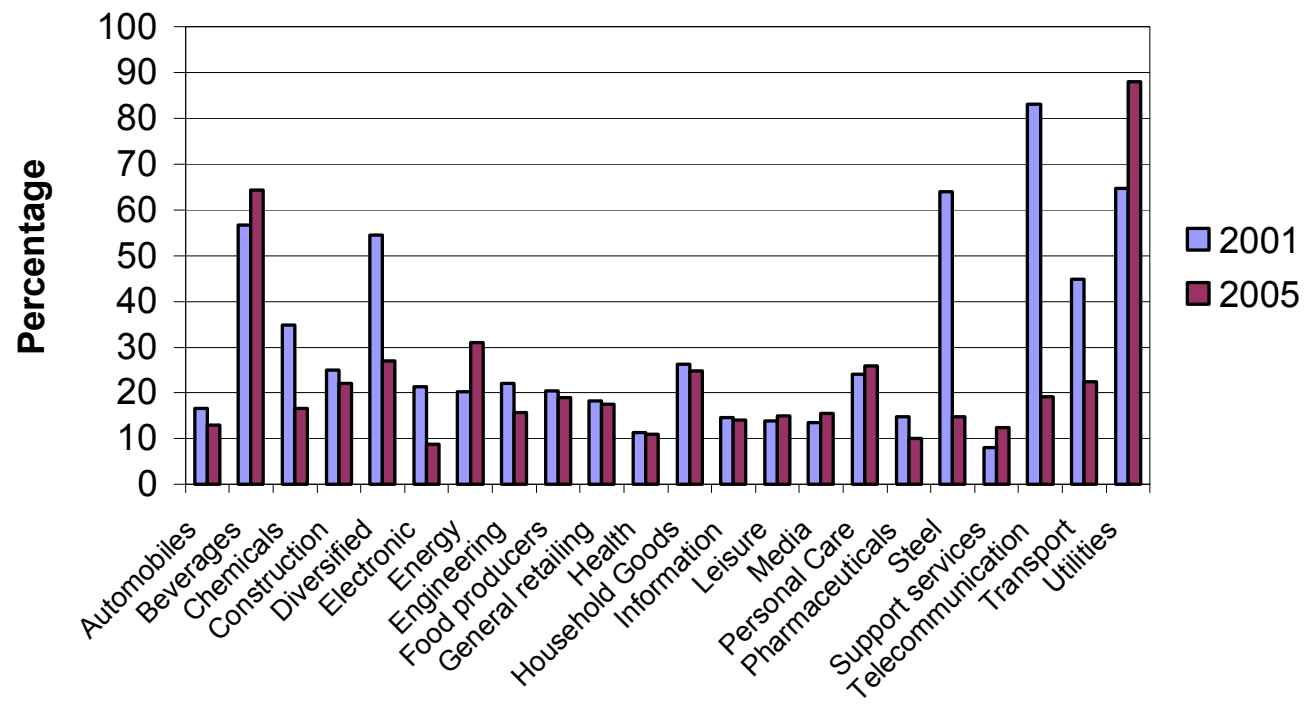

Figure 2: Median size of voting blocks in non-financial companies according to their industry classification

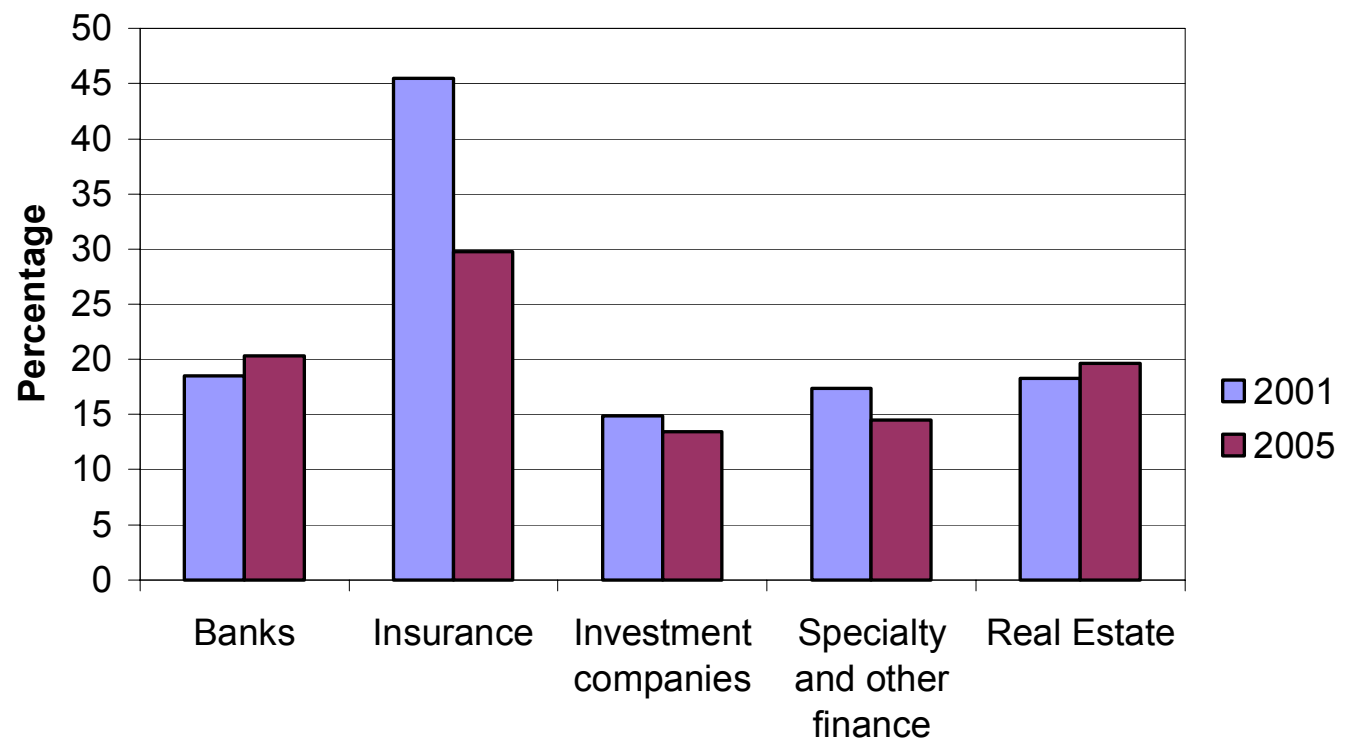

Figure 3: Median size of voting blocks in financial companies according to their industry classification 
Table 3: Holdings of entities in listed companies

\begin{tabular}{|c|c|c|c|c|c|c|}
\hline Blockholder & $\begin{array}{c}\text { Number of voting } \\
\text { blocks }\end{array}$ & $\%$ of total & $\begin{array}{c}\text { Number of voting } \\
\text { blocks }\end{array}$ & $\%$ of total & Mean & \\
\hline & 2001 & & 2005 & & 2001 & 2005 \\
\hline Industrial Firm & 188 & 20.41 & 266 & 15.84 & 53.27 & 41.03 \\
\hline Individual & 311 & 33.77 & 717 & 42.70 & 24.88 & 25.10 \\
\hline Banks: Big3 & 39 & 4.23 & 20 & 1.19 & 25.14 & 26.35 \\
\hline Banks: Other Domestic & 45 & 4.89 & 68 & 4.05 & 30.31 & 26.68 \\
\hline Holding & 75 & 8.14 & 100 & 5.96 & 42.66 & 36.39 \\
\hline Investment Firm & 54 & 5.86 & 141 & 8.40 & 30.88 & 25.36 \\
\hline Insurance Company & 51 & 5.54 & 54 & 3.22 & 27.75 & 22.39 \\
\hline Other Financial & 11 & 1.19 & 33 & 1.97 & 31.81 & 16.91 \\
\hline Public & 27 & 2.93 & 29 & 1.73 & 42.42 & 51.88 \\
\hline Association,Family Pool & 10 & 1.09 & 20 & 1.19 & 30.73 & 21.26 \\
\hline Foundation & 7 & 0.76 & 18 & 1.07 & 24.08 & 28.34 \\
\hline Foreign Company & 101 & 10.97 & 207 & 12.33 & 49.26 & 35.97 \\
\hline Other & 2 & 0.22 & 6 & 0.36 & 39.06 & 30.62 \\
\hline Total & 921 & 100.00 & 1679 & 100.00 & 36.29 & 29.96 \\
\hline
\end{tabular}

Table 4: Holdings on entities in non-financial listed companies

\begin{tabular}{lrrrrrr}
\hline \multicolumn{1}{c}{ Blockholder } & $\begin{array}{c}\text { Number of voting } \\
\text { blocks }\end{array}$ & \% of total & $\begin{array}{c}\text { Number of voting } \\
\text { blocks }\end{array}$ & \% of total & Mean \\
\hline & 2001 & & 2005 & & 2001 & 2005 \\
Industrial Firm & 169 & 24.71 & 239 & 17.46 & 53.90 & 41.52 \\
Individual & 236 & 34.50 & 601 & 43.90 & 27.17 & 25.30 \\
Banks: Big3 & 27 & 3.95 & 15 & 1.10 & 15.00 & 18.99 \\
Banks: Other Domestic & 20 & 2.92 & 44 & 3.21 & 29.67 & 21.25 \\
Holding & 52 & 7.60 & 71 & 5.19 & 43.16 & 35.15 \\
Investment Firm & 35 & 5.12 & 105 & 7.67 & 32.57 & 23.47 \\
Insurance Company & 22 & 3.22 & 32 & 2.34 & 24.29 & 17.51 \\
Other Financial & 9 & 1.32 & 24 & 1.75 & 34.53 & 11.88 \\
Public & 21 & 3.07 & 19 & 1.39 & 40.85 & 50.15 \\
Association,Family Pool & 9 & 1.32 & 20 & 1.46 & 32.29 & 21.26 \\
Foundation & 5 & 0.73 & 15 & 1.10 & 20.46 & 24.25 \\
Foreign Company & 75 & 10.96 & 178 & 13.00 & 45.56 & 33.77 \\
Other & 4 & 0.58 & 6 & 0.44 & 39.06 & 30.62 \\
Total & 684 & 100.00 & 1369 & 100.00 & 37.45 & 29.28 \\
\hline
\end{tabular}


Table 5: Number of blocks held by blockholders

\begin{tabular}{|c|c|c|c|c|}
\hline \multirow[t]{2}{*}{ No. of blocks } & \multicolumn{2}{|l|}{2001} & \multicolumn{2}{|l|}{2005} \\
\hline & iency $\mathrm{H}$ & ercent $\mathrm{F}$ & uency $F$ & ercent \\
\hline 1 & 598 & 87.17 & 1173 & 88.80 \\
\hline 2 & 51 & 7.43 & 81 & 6.13 \\
\hline 3 & 12 & 1.75 & 32 & 2.42 \\
\hline 4 & 9 & 1.31 & 8 & 0.61 \\
\hline 5 & 2 & 0.29 & 6 & 0.45 \\
\hline 6 & 5 & 0.73 & 5 & 0.38 \\
\hline 7 & 2 & 0.29 & 3 & 0.23 \\
\hline 8 & 0 & 0.00 & 5 & 0.38 \\
\hline 9 & 1 & 0.15 & 1 & 0.08 \\
\hline 10 & 0 & 0.00 & 1 & 0.08 \\
\hline 11 & 2 & 0.29 & 4 & 0.30 \\
\hline 12 & 1 & 0.15 & 1 & 0.08 \\
\hline 13 & 1 & 0.15 & 0 & 0.00 \\
\hline 19 & 1 & 0.15 & 0 & 0.00 \\
\hline 20 & 1 & 0.15 & 0 & 0.00 \\
\hline 21 & 0 & 0.00 & 1 & 0.08 \\
\hline Total & 686 & 100.00 & 1321 & 100.00 \\
\hline
\end{tabular}


Table 6: Shareholders controlling more than four votes in either 2001 or 2005

\begin{tabular}{|c|c|c|c|c|}
\hline \multirow[b]{2}{*}{ Name } & \multicolumn{2}{|l|}{2001} & \multicolumn{2}{|c|}{2005} \\
\hline & Number & $\operatorname{an}(\%) !$ & er 1 & $\operatorname{an}(\%)$ \\
\hline Deutsche Bank AG & 20 & 23.40 & 10 & 28.84 \\
\hline Allianz AG & 19 & 25.92 & 21 & 23.55 \\
\hline Dresdner Bank AG & 13 & 23.89 & 0 & \\
\hline E.ON AG & 12 & 51.48 & 8 & 72.50 \\
\hline Bayerische Hypo- und Vereinsbank AG & 11 & 52.60 & 11 & 37.77 \\
\hline RWE & 11 & 62.16 & 7 & 57.81 \\
\hline Münchener Rückversicherungs-Gesellschaft AG & 9 & 30.99 & 11 & 27.25 \\
\hline Assicurazioni Generali S.p.A. & 7 & 66.00 & 6 & 63.67 \\
\hline Bayerische Landesbank Girozentrale & 7 & 25.48 & 6 & 21.78 \\
\hline Commerzbank AG & 6 & 33.65 & 9 & 25.70 \\
\hline Energie Baden-Württemberg AG & 6 & 39.06 & 4 & 54.81 \\
\hline Merckle, Adolf & 6 & 20.97 & 8 & 33.13 \\
\hline WCM Beteiligungs- und Grundbesitz AG & 6 & 46.60 & 11 & 51.31 \\
\hline Wüstenrot und Württembergische AG & 6 & 38.00 & 4 & 48.84 \\
\hline GIE AXA S.A. & 5 & 38.71 & 7 & 17.96 \\
\hline Oetker, Rudolf August & 5 & 90.42 & 5 & 58.81 \\
\hline Siemens AG & 4 & 47.64 & 5 & 27.85 \\
\hline Westdeutsche Landesbank, Girozentrale & 4 & 14.84 & 6 & 13.00 \\
\hline SüdKA SüdKapitalanlagegesellschaft mbH & 0 & & 12 & 6.98 \\
\hline Fidelity International Limited & 0 & & 11 & 6.28 \\
\hline Bundesrepublik Deutschland & 2 & 76.42 & 8 & 67.92 \\
\hline DWS Investment GmbH & 0 & & 8 & 5.64 \\
\hline Landesbank Baden-Württemberg & 3 & 27.15 & 8 & 49.85 \\
\hline $\begin{array}{l}\text { Baden-Württembergische Versorgungsanstalt für Ärzte, } \\
\text { Zahnärzte und Tierärzte }\end{array}$ & 0 & & 7 & 7.40 \\
\hline HSBC Bank plc. & 1 & 73.46 & 6 & 18.66 \\
\hline The Capital Group Companies, Inc. & 0 & & 6 & 6.63 \\
\hline Barclays Bank PLC & 0 & & 5 & 5.98 \\
\hline Deutsche Balaton AG & 1 & 5.00 & 5 & 18.98 \\
\hline Julius Baer Multistock & 0 & & 5 & 7.68 \\
\hline Universal-Investment-Gesellschaft $\mathrm{mbH}$ & 0 & & 5 & 7.92 \\
\hline
\end{tabular}


Table 7: Crossholdings between the top-7 institutional holders

\begin{tabular}{|c|c|c|c|}
\hline \multirow[t]{2}{*}{ Name } & Holders & \multicolumn{2}{|c|}{ Voting block (\%) } \\
\hline & & 2001 & 2005 \\
\hline Allianz Aktiengesellschaft & $\begin{array}{l}\text { Bayerische Hypo- und Vereinsbank } \\
\text { Aktiengesellschaft }\end{array}$ & 6.8 & No voting rights \\
\hline & Deutsche Bank Aktiengesellschaft & 9.31 & No voting rights \\
\hline & Dresdner Bank Aktiengesellschaft & 10 & No voting rights \\
\hline & $\begin{array}{l}\text { Münchener Rückversicherungs- } \\
\text { Gesellschaft Aktiengesellschaft }\end{array}$ & 24.99 & 9.9 \\
\hline \multirow{3}{*}{$\begin{array}{l}\text { Bayerische Hypo- und Vereinsbank } \\
\text { Aktiengesellschaft }\end{array}$} & Allianz Aktiengesellschaft & 18.27 & No voting rights \\
\hline & E.ON Aktiengesellschaft & 8.7 & 6.72 \\
\hline & $\begin{array}{l}\text { Münchener Rückversicherungs- } \\
\text { Gesellschaft Aktiengesellschaft }\end{array}$ & 5.4 & 18.4 \\
\hline Dresdner Bank Aktiengesellschaft & Allianz Aktiengesellschaft & 21.97 & $\mathrm{~N} / \mathrm{A}$ \\
\hline E.ON Aktiengesellschaft & Allianz Aktiengesellschaft & 11.46 & No voting rights \\
\hline \multirow{4}{*}{$\begin{array}{l}\text { Münchener Rückversicherungs- } \\
\text { Gesellschaft Aktiengesellschaft }\end{array}$} & Allianz Aktiengesellschaft & 24.9 & 9.4 \\
\hline & $\begin{array}{l}\text { Bayerische Hypo- und Vereinsbank } \\
\text { Aktiengesellschaft }\end{array}$ & 13.29 & 9.97 \\
\hline & Deutsche Bank Aktiengesellschaft & 9.92 & No voting rights \\
\hline & Dresdner Bank Aktiengesellschaft & 9.1 & No voting rights \\
\hline RWE Aktiengesellschaft & Allianz Aktiengesellschaft & 13.32 & 7.55 \\
\hline
\end{tabular}

